\title{
GMR
}

\section{Diallel analysis for agronomic traits in upland cotton in semi-arid zones in Brazil}

\author{
D.R. Queiroz ${ }^{1}$, F.J.C. Farias², J.J.C. Vasconcelos ${ }^{2}$, L.P. Carvalho², \\ D.G. Neder ${ }^{3}$, L.S.S. Souza ${ }^{4}$, F.C. Farias ${ }^{5}$ and P.E. Teodoro ${ }^{6}$ \\ ${ }^{1}$ Departamento de Agronomia, Universidade Estadual da Paraíba, \\ Campina Grande, PB, Brasil \\ ${ }^{2}$ Empresa Brasileira de Pesquisa Agropecuária, Embrapa Algodão, \\ Campina Grande, PB, Brasil \\ ${ }^{3}$ Centro de Ciências Agrárias e Ambientais, Universidade Estadual da Paraíba, \\ Lagoa Seca, PB, Brasil \\ ${ }^{4}$ Centro de Ciências Agrárias, Universidade Federal da Paraíba, \\ Areia, PB, Brasil \\ ${ }^{5}$ Departamento de Agronomia, Universidade Federal de Goiás, \\ Goiânia, GO, Brasil \\ ${ }^{6}$ Departamento de Agronomia, Universidade Federal do Mato Grosso do Sul, \\ Chapadão do Sul, MS, Brasil \\ Corresponding author: P.E. Teodoro \\ E-mail: eduteodoro@hotmail.com
}

Genet. Mol. Res. 16 (3): gmr16039677

Received March 20, 2017

Accepted April 25, 2017

Published July 28, 2017

DOI http://dx.doi.org/10.4238/gmr16039677

Copyright (C) 2017 The Authors. This is an open-access article distributed under the terms of the Creative Commons Attribution ShareAlike (CC BY-SA) 4.0 License.

ABSTRACT. This study aimed to estimate the general- (GCA) and
specific-combining ability (SCA) and obtain information on the genetic
control of agronomic traits among six upland cotton genotypes and their
hybrid combinations. In 2015, six cotton genotypes (FM 993, CNPA
04-2080, PSC 355, TAM B 139-17, IAC 26, and TAMCOT-CAMD-E),
and fifteen hybrid combinations were evaluated at the Experimental
Station of Embrapa Algodão. The experiment consisted of a randomized
block design with three replications. The characteristics evaluated
were: the appearance of the first flower (AFF); the appearance of the

Genetics and Molecular Research 16 (3): gmr16039677 
first boll (AFB); plant height (PH); the weight of one boll (BW); lint percentage (LP); cotton seed yield (CSY); and cotton fiber yield (LY). Significant genetic variability was observed for all the traits studied, which is fundamental for the formation of populations that maximize genetic gains. Additive effects were predominant for AFF, AFB, PH, and LP. Non-additive effects were predominant for CSY, LY, and BW. Genotypes FM 993 and CNPA 04-2080 presented the highest GCA estimates for CSY, LP, and LY, as well as the highest means, being indicated for breeding programs that aim at the improvement of these traits. The best hybrid combinations were FM 993 x PSC 355, FM 993 x TAMCOT-CAMD-E, CNPA 04-2080 x TAM B 139-17, PSC 355 x IAC 26, and TAM B 139-17 x IAC 26, since they presented means associated with positive and high SCA estimates for CSY, LP, LY, and at least one of their parents presented high GCA.

Key words: Gossypium hirsutum; General-combining ability; Specific-combining ability; Fiber; Earliness

\section{INTRODUCTION}

Upland cotton (Gossypium hirsutum L.), denominated annual or herbaceous cotton, is one of the four species cultivated worldwide for fiber production. The species is exploited in large areas in tropical and subtropical regions and is of great importance in Brazil. Also, it is responsible for providing $90 \%$ of the world textile fiber.

The efficient choice of the parents to be used in crosses and the selection of the best hybrid combinations increases the chances of obtaining a successful breeding program and promising segregating populations. In this context, information on the general - (GCA) and specific-combining abilities (SCA) and on the heterotic expression between the crosses are useful (Carvalho, 1993; Aguiar et al., 2007). Diallel cross systems have been widely used in plant breeding programs to obtain information on the behavior of a group of parents per se and their hybrid combinations (Cruz and Vencovsky, 1989; Cruz et al., 2004).

There are several methodologies used to estimate GCA and SCA. The methodology proposed by Griffing (1956) is applied to a group of parents with any level of endogamy (Cruz and Vencovsky, 1989). The estimates of the effects of GCA provide information on the concentration of genes of predominant additive effect and are useful in the indication of parents to be employed in intrapopulation breeding programs. The significance of the SCA reflects the non-additive genetic effects, which indicates relevant non-allelic interactions. In this case, the breeder is interested in hybrid combinations with more favorable SCA estimates, with at least one parent with favorable effects of GCA (Sprague and Tatum, 1942; Cruz et al., 2004).

Several works have used diallel crosses to estimate the GCA and SCA in various traits of upland cotton. Aguiar et al. (2007) estimated GCA and SCA and the heterosis to study the genetic control of the agronomic and technological fiber traits in hybrid combinations of upland cotton. Studies on combining ability and heterosis have been carried out in cotton germplasm to estimate combining abilities and heterotic effects (Khan et al., 2009; Basal et al., 2011).

Berger et al. (2012) evaluated the fiber quality in eight upland cotton genotypes using diallel analysis and observed significant effects of GCA and SCA values for most of the fiber

Genetics and Molecular Research 16 (3): gmr16039677 
traits evaluated, including lint percentage. Simon et al. (2013) studied the effects of combining abilities on eight cotton genotypes in northeastern Nigeria and observed both additive and nonadditive effects on the genetic control of the traits under study. Bechere et al. (2016) studied the effects of SCA and GCA estimates for the ginning rate and the net ginning energy requirement on a set of upland cotton germplasm (Gossypium hirsutum L.), and found both additive and nonadditive effects, with a predominance of additive effects in the control of the traits under study.

This study aimed to estimate the GCA and SCA and to obtain information on the genetic control of agronomic traits among six upland cotton genotypes and their hybrid combinations.

\section{MATERIAL AND METHODS}

In 2015, six cotton genotypes (FM 993, CNPA 04-2080, PSC 355, TAM B 13917, IAC 26, and TAMCOT-CAMD-E) and 15 hybrid combinations were evaluated at the Experimental Station of Embrapa Algodão, located in Patos - PB (latitude $7^{\circ} 0{ }^{\prime} 40.55 " \mathrm{~S}$; longitude $37^{\circ} 16^{\prime} 14.80^{\prime \prime} \mathrm{W}$, at $243.28 \mathrm{~m}$ asl). The average rainfall recorded in the year of 2015 was of 495.7 mm (AESA - Agência Executiva de Gestão das Águas do Estado da Paraíba, 2017). The experiment was carried out under irrigation regime. The experimental plot consisted of two $5 \mathrm{~m}$ rows, spaced $1.0 \mathrm{~m}$ between rows and $0.20 \mathrm{~m}$ between plants, with a useful area of $10 \mathrm{~m}^{2}$, and a population density of 50 plants/row. The experiment consisted of randomized block design with three replications.

Planting was carried out manually, with 25 plants in each $5.0 \mathrm{~m}$ row. Thinning was performed 30 days after planting. Cultural treatments were carried out according to the culture's need throughout the experiment. The following traits were evaluated: characteristic appearance of the first flower (AFF, days), appearance of the first boll (AFB, days), plant height $(\mathrm{PH}, \mathrm{cm})$, cotton seed yield (CSY, $\mathrm{kg} / \mathrm{ha})$, lint percentage (LP, \%), cotton fiber yield (LY, $\mathrm{kg} / \mathrm{ha}$ ), and weight of one boll (BW, g).

Statistical genetic analyses for the data obtained in the experiment were carried out using the GENES software (Cruz, 2013). The F-test at 1 and 5\% probability was used for analysis of variance. Means between treatments were compared using the Scott and Knott (1974) test at 5\% probability. Diallel analyses and estimates of combining abilities were carried out according to method 2, model 1 of Griffing (1956), which estimates the effects of the GCA $\left(\hat{\mathrm{g}}_{\mathrm{i}}\right)$ of each parent, as well as the effects of the SCA $\left(\hat{\mathrm{s}}_{\mathrm{ij}}\right)$. The model was considered fixed for genotype effects. The statistical genetic model is given by Equation 1:

$$
Y_{i j}=m+g_{i}+g_{j}+s_{i j}+\bar{e}_{i j} \quad \text { (Equation 1) }
$$

where $Y_{i j}$ : mean value of hybrid combination $(i \neq \mathrm{j})$ or of the parent combination $(\mathrm{i}=\mathrm{j}) ; m$ : general mean; $g_{i}, g_{j}$ : effects of the GCA of the $i$-th and the $j$-th parent, respectively; $s_{i j}$ : effects of the SCA for crosses between the parents $i$ and $j$; $\bar{e}_{i j}$ : mean experimental error.

\section{RESULTS AND DISCUSSION}

\section{Combining abilities}

Table 1 shows the diallel analyses for the traits under study. All traits were significant

Genetics and Molecular Research 16 (3): gmr16039677 
for GCA, indicating that at least one parent was superior to the others concerning the mean performance in their hybrid combinations. The means of all traits evaluated are demonstrated in Table S1. AFF, AFB, and PH, showed no significance for SCA. Except for yield, GCA was predominant in all traits related to SCA, indicating greater importance of additive effects in the control of the traits under study. These results are in agreement with those obtained by Aguiar et al. (2007) who estimated the GCA and SCA in 28 hybrid combinations of upland cotton.

Table 1. Analysis of variance for genotypes and for general-combining ability (GCA) and specific-combining ability (SCA) of the characteristics: appearance of the first flower (AFF, days), appearance of the first boll (AFB, days), plant height ( $\mathrm{PH}, \mathrm{cm})$, cotton seed yield (CSY, $\mathrm{kg} / \mathrm{ha}$ ), lint percentage (LP, \%), cotton fiber yield (LY, $\mathrm{kg} /$ ha), and weight of one boll (BW, g) according to the Griffing model (1956) involving parents and $\mathrm{F}_{1}$ hybrids.

\begin{tabular}{|c|c|c|c|c|c|c|c|c|}
\hline Sources of variation & d.f. & AFF & AFB & $\mathrm{PH}$ & CSY & LP & LY & BW \\
\hline Genotypes & 20 & $10.46^{* * *}$ & $19.14 * *$ & $153.26^{* * *}$ & $3718996.27^{* *}$ & $4.84 * *$ & $668444.84^{* *}$ & $0.96^{* *}$ \\
\hline GCA & 5 & $36.14 * *$ & $71.11^{* *}$ & $536.22 * *$ & $3300854.79 *$ & $13.75^{* *}$ & $721222.06 * *$ & $1.88^{* *}$ \\
\hline SCA & 15 & $1.90^{\mathrm{ns}}$ & $1.81^{\mathrm{ns}}$ & $25.61^{\mathrm{ns}}$ & $3858376.76^{* *}$ & $1.87 * *$ & $650852.43 * *$ & $0.65^{* *}$ \\
\hline Residual & 40 & 2.43 & 2.35 & 59.39 & 942289.69 & 0.71 & 170856.76 & 0.07 \\
\hline ФGCA & & 1.40 & 2.86 & 19.86 & 98273.54 & 0.54 & 22931.88 & 0.07 \\
\hline ФSCA & & -0.17 & -0.17 & -11.25 & 972029.02 & 0.38 & 159998.55 & 0.19 \\
\hline Mean & & 43.07 & 85.44 & 69.00 & 4518.46 & 41.57 & 1881.51 & 6.21 \\
\hline CV (\%) & & 3.62 & 1.79 & 11.16 & 21.48 & 2.03 & 21.96 & 4.35 \\
\hline
\end{tabular}

*** ${ }^{*}$ Significant at 1 and 5\% probability by the F-test, respectively; $\Phi$ GCA $=$ quadratic component associated with GCA; $\Phi S C A=$ quadratic component associated with SCA; d.f. = degrees of freedom; CV = coefficient of variation.

Quadratic effects associated with GCA were predominant for AFF, AFB, PH, and LP, which indicates a predominance of the additive genetic effects. For AFF, these results were in agreement with those obtained by Khan et al. (2011), Alkuddsi et al. (2013), and Khan (2013). Variance associated with SCA concerning GCA was predominant for flowering, which evidences the predominance of the non-additive effects for this trait; this fact does not agree with the present results. Conversely, for SCA, quadratic effects were more important for CSY, LY, and BW.

According to Usharani et al. (2014), additive effects were predominant in a study on combining abilities for AFB. On the other hand, non-additive effects were predominant in the study of Pusphpam et al. (2015). For PH, the present results were similar to those observed by Méndez-Natera et al. (2012), Patel et al. (2014), Usharani et al. (2014), Kumar et al. (2014), and Waqar et al. (2015).

For CSY, Rauf et al. (2006) observed similar results when studying cotton yield components, i.e., both additive and dominance effects controlled yield. Conversely, Aguiar et al. (2007), Khan et al. (2011), Hinze et al. (2011), Khan (2013), Srinivas et al. (2014), and Patel et al. (2014) observed predominant GCA variance over SCA variance. Other authors have observed predominant SCA (Kumar et al., 2014; Ekinci and Basbag, 2015; Kannan and Saravanan, 2015; Çoban and Ünay, 2015; Pusphpam et al., 2015).

For LP, similar results were found by Hinze et al. (2011), Khan et al. (2011), Khan (2013), and Zeng and Pettigrew (2015). Other authors, such as Basal et al. (2011) and Imran et al. (2012), found non-additive genetic effects in the control of this trait. For LY, in the study of Ashokkumar et al. (2010) on GCA and SCA in yield components, non-additive effects were predominant for most of the traits.

\section{GCA effects}

Table 2 shows the estimates of the effects of the GCA $\left(\hat{\mathrm{g}}_{\mathrm{i}}\right)$ of the parents under study. 
Regarding AFF and AFB, the genotype TAMCOT-CAMD-E obtained the highest negative estimate and the lowest mean estimate for both traits. It should be noticed that the fewer the days for the AFF and AFB, the higher is earliness. In this case, the genotype with the lowest $\left(\hat{\mathrm{g}}_{\mathrm{i}}\right)$ estimate is recommended.

Table 2. Estimates of the effects of the general-combination ability $\left(\hat{\mathrm{g}}_{\mathrm{i}}\right)$ of six cotton parents for the characteristics: appearance of the first flower (AFF, days), appearance of the first boll (AFB, days), plant height (PH, cm), cotton seed yield (CSY, kg/ha), lint percentage (LP, \%), cotton fiber yield (LY, kg/ha), and weight of one boll (BW, g).

\begin{tabular}{l|c|c|c|c|c|c|c}
\hline Parents & AFF & AFB & PH & CSY & LP & LY & BW \\
\hline FM 993 & 0.11 & $1.78^{* *}$ & $3.49^{*}$ & $372.93^{*}$ & $0.87^{* *}$ & $190.51^{*}$ & -0.09 \\
\hline CNPA 04-2080 & -0.29 & -0.14 & -0.80 & 197.72 & $0.68^{* *}$ & 112.24 & 0.00 \\
\hline PSC 355 & 0.13 & -0.42 & -0.87 & 103.06 & -0.25 & 32.29 & $-0.42^{* *}$ \\
\hline TAM B 139-17 & 0.39 & $0.85^{* *}$ & $-4.49^{* *}$ & -227.66 & -1.24 & -147.73 & $0.43^{* *}$ \\
\hline IAC 26 & $1.72^{* *}$ & $1.02^{* *}$ & $7.43^{* *}$ & 193.83 & 0.03 & 80.90 & $0.12^{*}$ \\
\hline TAMCOT-CAMD-E & $-2.06^{* *}$ & $-3.10^{* *}$ & $-4.76^{* *}$ & $-639.90^{* *}$ & $-0.08^{* *}$ & $-268.22^{* *}$ & -0.05 \\
\hline SD $\left(\mathrm{g}_{\mathrm{i}}\right)$ & 0.29 & 0.28 & 1.43 & 180.88 & 0.15 & 77.02 & 0.05 \\
\hline SD $\left(\mathrm{g}_{\mathrm{i}}-\mathrm{g}_{\mathrm{j}}\right)$ & 0.45 & 0.44 & 2.22 & 280.22 & 0.24 & 119.32 & 0.07 \\
\hline
\end{tabular}

**, ${ }^{*}$ Significant at 1 and $5 \%$ probability by the $t$-test; SD $\left(g_{\mathrm{i}}\right)=$ standard deviation; $\mathrm{SD}\left(\mathrm{g}_{\mathrm{i}}-\mathrm{g}_{\mathrm{j}}\right)=$ standard deviation of the difference of the effects of two parents.

For $\mathrm{PH}$, the highest positive estimate was observed for the genotype IAC 26 that also obtained the highest mean. The genotype TAMCOT-CAMD-E and TAM B 139-17 obtained the highest negative $\left(\hat{\mathrm{g}}_{\mathrm{i}}\right)$ estimates and lower mean values, respectively (Table 2). Depending on the breeding program, lower height may be desired. In this study, genotypes TAMCOTCAMD-E and TAM B 139-17 presented the highest $\left(\hat{\mathrm{g}}_{\mathrm{i}}\right)$ negative estimates, contributing to a reduction in plant height.

In relation to CSY, only two genotypes presented negative estimates. The genotype FM 993 presented the highest positive estimate; however, it did not have the highest mean among the genotypes. Genotype CNPA 04-2080 presented the highest mean with positive estimates, followed by IAC 26. Regarding LP, genotype FM 993 presented the highest positive estimate and the highest mean estimate among genotypes. This trait is influenced by the environment. The position of the boll in the plant, in function of the height of the fruiting branch, and the position of this branch related to the stem significantly influence the level of lint percentage. The bolls of the upper and lower third of the plant showed lower lint percentage. Currently, breeding programs have selected genotypes with $40 \%$ or greater LP (Farias et al., 2008).

Regarding LY, except for TAMCOT-CAMD-E and TAM B 139-17, all genotypes presented positive $\left(\hat{\mathrm{g}}_{\mathrm{i}}\right)$ estimates. Genotype FM 993 stood out with the highest positive estimate; however, it did not present the highest mean among the genotypes. The genotypes CNPA 04-2080 and IAC 26 obtained the highest means $\left(\hat{\mathrm{g}}_{\mathrm{i}}\right)$ and positive estimates, meaning that they genetically contributed to increasing fiber yield. For BW, the genotype TAM B 13917 showed the highest positive estimates and the highest mean among the genotypes, meaning that this parent may genetically contribute to increasing the weight of one boll.

\section{SCA effects}

Table 3 shows the estimates of SCA effects $\left(\hat{\mathrm{s}}_{\mathrm{ij}}\right)$. Considering AFF, the hybrid CNPA 04-2080 x TAMCOT-CAMD-E presented the highest negative estimate, followed by the parents with a low $\left(\hat{\mathrm{g}}_{\mathrm{i}}\right)$ estimate. For AFB, the combination FM 993 x CNPA 04-2080 presented 
high and negative estimates and parents with negative $\left(\hat{g}_{\mathrm{i}}\right)$ estimates, which is important for the obtainment of earliness. For PH, the combination CNPA 04-2080 x PSC 355 presented the highest positive estimates; however, both parents showed negative $\left(\hat{g}_{i}\right)$ estimates. The combination FM 993 x PSC 355 obtained the lowest estimate, and the parents presented low $\left(\hat{g}_{\mathrm{i}}\right)$ estimates.

Table 3. Estimates of the effects of the specific-combining ability $\left(\hat{\mathrm{s}}_{\mathrm{i} . \mathrm{i}}\right)$ among six genotypes of cotton for the characteristics: appearance of the first flower (AFF, days), appearance of the first boll (AFB, days), plant height $(\mathrm{PH}, \mathrm{cm})$, cotton seed yield (CSY, kg/ha), lint percentage (LP, \%), cotton fiber yield (LY, kg/ha), and weight of one boll (BW, g).

\begin{tabular}{|c|c|c|c|c|c|c|c|}
\hline Genotypes & $\mathrm{AFF}$ & AFB & $\mathrm{PH}$ & CSY & LP & LY & BW \\
\hline FM $993 \times$ x FM 993 & 0.02 & 0.30 & 3.71 & $-1040.34 *$ & 0.62 & $-404.22 *$ & -0.42 \\
\hline CNPA 04-2080 x CNPA 04-2080 & -0.47 & -0.15 & -4.90 & 701.08 & -0.59 & 277.31 & $-0.57 * *$ \\
\hline PSC $355 \times$ PSC 355 & $-1.68^{*}$ & 0.05 & -0.29 & -278.26 & $-0.96 * *$ & -162.07 & $-0.60 * *$ \\
\hline TAM B 139-17 x TAM B 139-17 & -0.19 & -0.83 & -1.78 & 298.18 & -0.47 & 99.60 & $-0.84 * *$ \\
\hline IAC $26 \times$ IAC 26 & -0.19 & -1.16 & 0.06 & 372.51 & -0.58 & 127.15 & $-0.60^{* *}$ \\
\hline TAMCOT-CAMD-E x TAMCOT-CAMD-E & 0.06 & -0.57 & -0.90 & -493.33 & 0.09 & -204.85 & -0.10 \\
\hline FM $993 \times$ CNPA 04-2080 & 0.43 & -1.09 & -0.12 & $-1009.13^{*}$ & -0.09 & $-431.07 *$ & 0.00 \\
\hline FM $993 \times$ PSC 355 & 0.15 & -0.34 & -4.29 & $3188.25^{* *}$ & -0.63 & $1302.13^{* *}$ & 0.00 \\
\hline FM $993 \times$ TAM B 139-17 & -0.91 & 0.23 & -0.87 & -274.41 & 0.36 & -94.16 & $0.41^{* *}$ \\
\hline FM $993 \times$ IAC 26 & 0.41 & 0.73 & -2.39 & -1001.24 & -0.28 & $-428.57^{*}$ & $0.28^{*}$ \\
\hline FM 993 x TAMCOT-CAMD-E & -0.14 & -0.16 & 0.25 & $1177.22 *$ & -0.60 & $460.13 *$ & 0.13 \\
\hline CNPA $04-2080 \times$ PSC 355 & 0.56 & -0.91 & 4.65 & -869.52 & $1.10^{*}$ & -321.59 & $0.40^{* *}$ \\
\hline CNPA 04-2080 x TAM B 139-17 & 0.83 & 0.17 & 4.65 & 223.46 & 0.52 & 111.12 & $0.36^{* *}$ \\
\hline CNPA $04-2080 \times$ IAC 26 & -0.16 & 0.67 & 1.42 & -402.03 & $-1.03 *$ & -211.52 & $0.48 * *$ \\
\hline CNPA 04-2080 x TAMCOT-CAMD-E & -0.70 & 1.46 & -0.80 & 655.04 & 0.69 & 298.44 & -0.10 \\
\hline PSC $355 \times$ TAM B $139-17$ & 0.39 & 0.78 & -0.70 & -627.20 & 0.26 & -244.60 & $0.61^{* *}$ \\
\hline PSC $355 \times$ IAC 26 & 0.72 & 0.28 & -1.69 & 96.62 & $1.27 * *$ & 100.54 & 0.21 \\
\hline PSC $355 \times$ TAMCOT-CAMD-E & 1.52 & 0.07 & 2.63 & $-1231.63 *$ & -0.08 & $-512.32 *$ & -0.03 \\
\hline TAM B $139-17$ x IAC 26 & 0.14 & 0.66 & 1.65 & 128.68 & 0.60 & 75.11 & 0.15 \\
\hline TAM B 139-17 x TAMCOT-CAMD-E & -0.06 & -0.20 & -1.14 & -46.90 & -0.80 & -46.66 & 0.14 \\
\hline IAC $26 \times$ TAMCOT-CAMD-E & -0.73 & -0.03 & 0.89 & 432.92 & 0.60 & 210.13 & 0.07 \\
\hline $\mathrm{SD}\left(\mathrm{S}_{\mathrm{ii}}\right)$ & 0.65 & 0.64 & 3.25 & 410.20 & 0.35 & 174.67 & 0.11 \\
\hline $\mathrm{SD}\left(\mathrm{S}_{\mathrm{ij}}\right)$ & 0.79 & 0.78 & 3.94 & 496.77 & 0.43 & 211.53 & 0.13 \\
\hline $\mathrm{SD}\left(\mathrm{S}_{\mathrm{ii}}-\mathrm{S}_{\mathrm{ij}}\right)$ & 0.90 & 0.88 & 4.44 & 560.44 & 0.48 & 238.64 & 0.15 \\
\hline $\mathrm{SD}\left(\mathrm{S}_{\mathrm{ij}-}-\mathrm{S}_{\mathrm{ik}}\right)$ & 1.19 & 1.17 & 5.88 & 741.39 & 0.64 & 315.69 & 0.20 \\
\hline $\operatorname{SD}\left(S_{i j}-S_{k l}\right)$ & 1.10 & 1.08 & 5.44 & 686.39 & 0.59 & 292.28 & 0.19 \\
\hline
\end{tabular}

**,*Significant at 1 and $5 \%$ probability by $t$-test, respectively. $\mathrm{SD}=$ standard deviation.

For CSY and LY, the combination FM 993 x PSC 355 showed the best positive estimate, followed by parents with high and positive $\left(\hat{\mathrm{g}}_{\mathrm{i}}\right)$ estimates, and with high mean values, being indicated for yield improvement. For LP, the best combinations were PSC 355 x IAC 26 and CNPA 04-2080 x PSC 355; moreover, one of the parents presented positive $\left(\hat{g}_{i}\right)$ estimates and high mean values. Concerning BW, the combination PSC 355 x TAM B 139-17 presented the highest positive estimate, and parents presented positive $\left(\hat{\mathrm{g}}_{\mathrm{i}}\right)$ values, being indicated for the improvement of this trait.

\section{ACKNOWLEDGMENTS}

We thank Empresa Brasileira de Pesquisa Agropecuária - Embrapa Algodão.

\section{REFERENCES}

AESA - Agência Executiva de Gestão das Águas do Estado da Paraíba (2017). Chuvas acumuladas no ano 2015. Available at [http://site2.aesa.pb.gov.br/aesa/monitoramentoPluviometria.do]. Accessed January 29, 2017.

Aguiar PA, Penna JCV, Freire EC and Melo LC (2007). Diallel analysis of upland cotton cultivars. Crop Breed. Appl. Biotechnol. 7: 353-359. https://doi.org/10.12702/1984-7033.v07n04a04

Genetics and Molecular Research 16 (3): gmr16039677 
Alkuddsi YA, Rao MRG, Patil SS, Gowda TH, et al. (2013). Combining ability analysis for seed cotton yield (kapas yield) and its components in intra hirsutum hybrids and heterotic boxes for exploitation in cotton. Jiyinzuxue Yu Yingyong Shengwuxue 4: 35-49.

Ashokkumar K, Ravikesavan R and Prince KSJ (2010). Combining ability estimates for yield and fibre quality traits in line x tester crosses of upland cotton, (Gossypium hirsutum). Int. J. Biol. 2: 179-183. https://doi.org/10.5539/ijb. v2n1p179

Basal H, Canavar O, Khan NU and Cerit CS (2011). Combining ability and heterotic studies through line $\mathrm{x}$ tester in local and exotic upland cotton genotypes. Pak. J. Bot. 43: 1699-1706.

Bechere E, Zeng L and Hardin RG (2016). Combining ability of ginning rate and net ginning energy requirement in upland cotton. Crop Sci. 56: 499-504. https://doi.org/10.2135/cropsci2015.05.0297

Berger G, Hague S and Smith CW (2012). Diallel analysis of fiber traits for extra-long staple cotton progeny. Crop Sci. 52: 683-686. https://doi.org/10.2135/cropsci2010.11.0648

Carvalho LP (1993) Divergência genética e análise dialélica de Gossypium hirsutum L. var. latifolium Hutch. Tese Doutorado em Genética e Melhoramento, Universidade Federal de Viçosa, Viçosa, Brasil.

Cruz CD (2013). GENES - a software package for analysis in experimental statistic and quantitative genetics. Acta Sci. Agron. 35: 271-276. https://doi.org/10.4025/actasciagron.v35i3.21251

Cruz CD and Vencovsky R (1989). Comparação de alguns métodos de análise dialélica. Rev. Bras. Genet. 12: 425-438.

Cruz CD, Carneiro PCS and Regazzi AJ (2004). Modelos biométricos aplicados ao melhoramento genético. v.1. $3^{\mathrm{a}}$ edn. Viçosa, UFV.

Çoban M and Ünay A (2015). Combining ability for yield and fiber qualities in cotton crosses (Gossypium hirsutum L.). J. Int. Sci. Pub. Agric. Food 3: 178-185.

Ekinci R and Basbag S (2015). Combining ability for yield and its components in diallel crosses of cotton. Not. Sci. Biol. 7: 72-80. https://doi.org/10.15835/nsb.7.1.9430

Farias FJC, Freire EC, Beltrão NEM, Bélot JL, et al. (2008) Caracteres de importância econômica no melhoramento do algodoeiro. In O agronegócio do algodão no Brasil (Beltrão NEM and Azevedo DMP, eds.). $2^{\mathrm{a}}$ edn. Embrapa Informações Tecnológicas, Brasília.

Griffing B (1956). Concept of general and specific ability in relation to diallel crossing systems. Aust. J. Biol. Sci. 9: $462-$ 493. https://doi.org/10.1071/BI9560463

Hinze LL, Campbell BT and Kohel RJ (2011). Performance and combining ability in cotton (Gossypium hirsutum L.) populations with diverse parents. Euphytica 181: 115-125. https://doi.org/10.1007/s10681-011-0442-x

Imran M, Shakeel A, Azhar FM, Farooq J, et al. (2012). Combining ability analysis for within-boll yield components in upland cotton (Gossypium hirsutum L.). Genet. Mol. Res. 11: 2790-2800. https://doi.org/10.4238/2012.August.24.4

Kannan N and Saravanan K (2015). Heterosis and combining ability analysis in tetraploid cotton (G. hirsutum e G. barbadense L.). Int. J. Curr. Res. 7: 16590-16595.

Khan NU (2013). Combining ability analysis in intra specific F1 diallel cross of upland cotton. Scie. Papers. A. Agron. 56: 289-295.

Khan NU, Hassan G, Marwat KB, Tullah F, et al. (2009). Diallel analysis of some quatitative traits in Gossypium hirsutum L. Pak. J. Bot. 41: 3009-3022.

Khan SA, Khan NU, Mohammad F, Ahmad M, et al. (2011). Combining ability analysis in intraspecific F1 diallel cross of upland cotton. Pak. J. Bot. 43: 1719-1723.

Kumar K, Ashokkumar K and Ravikesavan R (2014). Genetic effects of combining ability studies for yield and fiber quality traits in diallel crosses of upland cotton (Gossypium hirsutum L.). Afr. J. Biotechnol. 13: 119-126. https://doi. org/10.5897/AJB2013.13079

Méndez-Natera JR, Rondón A, Hernández J and Merazo-Pinto F (2012). Genetic studies in upland cotton (Gossypium hirsutum L.) II. General and specific ability. J. Agr. Sci. Technol. 14: 617-627.

Patel DH, Patel DU and Kumar V (2014). Heterosis and combining ability analysis in tetraploid cotton (G. hirsutum L. and G. barbadense L.). Electron. J. Plant Breed. 5: 408-414.

Pusphpam R, Thanaraj K and Raveendran TS (2015). Heterosis and combinig ability studies in upland cotton for yield characters. Electron. J. Plant Breed. 6: 459-463.

Rauf S, Munir H, Basra SMA and Abdullojon E (2006). Combining ability analysis in upland cotton (Gossypium hirsutum L.). Int. J. Agric. Biol. 8: 341-343.

Scott AJ and Knott M (1974). A cluster analysis method for grouping means in the analysis ofvariance. Biometrics 30: 507-512. https://doi.org/10.2307/2529204

Simon SY, Kadams AM and Aliyu B (2013). Combining ability analysis in F1 hybrids of cotton (Gossypium species L.) by diallel method in northeastern Nigeria. Greener J. Agric. Sci. 3: 90-96.

Genetics and Molecular Research 16 (3): gmr16039677 
Sprague GF and Tatum LA (1942). General vs. specific combining ability in single crosses of corn. Agron. J. 34: 923-932. https://doi.org/10.2134/agronj1942.00021962003400100008x

Srinivas B, Bhadru D, Rao MVB and Gopinath M (2014). Combining ability studies for yield and fibre quality traits in upland cotton (Gossypium hirsutum L.). SABRAO J. Breed. Genet. 46: 313-318.

Usharani KS, Vindhiyavarman P and AmalaBalu P (2014). Combining ability analysis in intraspecific F1 diallel cross of upland cotton (Gossypium hirsutum L.). Electron. J. Plant Breed. 5: 467-474.

Waqar I, Khan IA, Khan AI, Shar SSM, et al. (2015). Genetic analysis of morphological and yield contributing traits in upland cotton (Gossypium hirsutum L.). Scie. Letters 3: 57-61.

Zeng L and Pettigrew WT (2015). Combining ability, heretability, and genotypic correlations for lint yield and fiber quality of upland cotton in delayed planting. Field Crops Res. 171: 176-183. https://doi.org/10.1016/j.fcr.2014.10.004

\section{Supplementary material}

Table S1. Means of the parents and their hybrid combinations for the characteristics: appearance of the first flower (AFF, days), appearance of the first boll (AFB, days), plant height $(\mathrm{PH}, \mathrm{cm})$, cotton seed yield (CSY, $\mathrm{kg} / \mathrm{ha})$, lint percentage (LP, \%), cotton fiber yield (LY, kg/ha), and weight of one boll (BW, g) evaluated in 21 cotton genotypes.

Genetics and Molecular Research 16 (3): gmr16039677 